\title{
Strategi Peningkatan Kompetensi Pedagogik dan Profesional Guru MI Melalui Supervisi Akademik Kepala Madrasah
}

\author{
Muh. Nurul Wathani \\ Kemenag Kab. Lombok Utara \\ email: muh.nurulwathaniklu@gmail.com
}

\begin{abstract}
The purpose of this research is to analyze and describe the implementation of academic supervision of madrasah principals as supervisors, obstacles and solutions offered in the implementation of academic supervision, and the implications of the academic supervision activities. This research was carried out through field research using a qualitative method and a phenomenological approach to a multi-site case study. Data mining techniques are observation, interview and documentation. Data analysis is through reduction, display and verification, while data validity is tested through perseverance of observation and triangulation. The results of this thesis study show that: 1) The urgency of the implementation of adakamic supervision by the heads of madrasas KKM members in improving pedagogical and professional competence of MI Riadlul Jannah NW Penjor as a KKM program departs from the results of the analysis of the need to improve teacher professionalism. This is also reinforced by a number of inhibiting factors experienced by teachers in the process of learning activities in class. 2) The implementation of the academic supervision of madrasa principals through role exchange techniques in enhancing the pedagogical and professional competence of MI Riadlul Jannah NW Penjor teachers is done through planning, implementing and evaluating activities. 3) Implications for the academic supervision of madrasa head of role-changing techniques for MI Riadlul Jannah NW Penjor are broadly divided into two parts, namely the beneficial implications for the development of institutions or madrassas providing supervision, and also the positive implications for teachers in developing pedagogical and professional competencies.
\end{abstract}

Keywords: Improvement Strategies, Teacher Competence, Academic Supervision

\section{ABSTRAK}

Tujuan diadakannya penelitian ini untuk menganalisis dan mendeskripsikan tentang implementasi supervisi akademik para kepala madrasah selaku supervisor, hambatan dan solusi yang ditawarkan dalam pelaksanaan supervisi akademik, dan implikasi dari kegiatan supervisi akademik tersebut. Penelitian ini dilaksanakan melalui kajian di lapangan (field research) menggunakan metode kualitatif dan pendekatan fenomenologis studi kasus multisitus (multysite case study). Penggalian data dengan teknik observasi, wawancara dan dokumentasi. Analisis data melalui reduksi, displai dan verifikasi, sedangkan uji keabsahan data melalui ketekunan pengamatan dan triangulasi. Hasil penelitian tesis ini menunjukkan bahwa: 1) Urgensi pelaksanaan supervisi adakamik oleh para kepala madrasah anggota KKM dalam peningkatan kompetensi pedagogik dan profesional guru MI Riadlul Jannah NW Penjor sebagai sebuah program KKM berangkat dari hasil analisis kebutuhan peningkatan profesionalisme guru. Hal ini diperkuat juga dari sejumlah faktor penghambat yang dialami oleh guru dalam proses kegiatan pembelajaran di kelas. 2) Implementasi supervisi akademik kepala madrasah melalui teknik tukar peran dalam peningkatan kompetensi pedagogik dan profesional guru MI Riadlul Jannah NW Penjor dilakukan melalui kegiatan perencanaan, pelaksanaan dan evaluasi. 3) Implikasi supervisi akademik kepala madrasah teknik tukar peran bagi MI Riadlul Jannah NW Penjor secara garis besar terbagi menjadi dua bagian yaitu implikasi yang bermanfaat bagi pengembangan lembaga atau madrasah penyelenggara supervisi, dan juga implikasi positif bagi guru dalam mengembangkan kompetensi pedagogik dan kompetensi profesionalnya.

Kata kunci: Strategi Peningkatan, Kompetensi Guru, Supervisi Akademik

\begin{tabular}{c|c|c} 
First Receive: & Revised: & Accepted: \\
28 February 2020 & 7 June 2020 & 26 June 2020
\end{tabular}

Copyright (C2020 Schemata Journal

Available online at http:/ /journal.uinmataram.ac.id/index.php/schemata 


\begin{tabular}{|c|c|}
\hline $\begin{array}{c}\text { Final Proof Recieved: } \\
\text { 28 June 2020 }\end{array}$ & $\begin{array}{c}\text { Published: } \\
\text { 30 June 2020 }\end{array}$ \\
\hline \multicolumn{3}{|c|}{$\begin{array}{c}\text { How to cite (in APA style): } \\
\text { Wathani, M. N., (2020). Strategi Peningkatan Kompetensi Pedagogik dan Profesional } \\
\text { Guru MI Melalui Supervisi Akademik Kepala Madrasah. Schemata, 9 (1), 53-72. }\end{array}$} \\
\hline
\end{tabular}

\section{PENDAHULUAN}

Pendidikan merupakan bagian yang integral dalam kehidupan manusia, dimana manusia dapat membina kepribadiannya dengan jalan membina potensi-potensi pribadinya sesuai dengan nilai-nilai di dalam masyarakat dan kebudayaan. Dengan demikian dari nilainilai yang ada berlangsung suatu proses pendidikan sesuai dengan tujuan utama pendidikan yaitu mengembangkan kemampuan pengetahuan keterampilan dan sikap anak didik secara optimal.Dalam dunia pendidikan, guru merupakan orang yang sangat dominan dan paling penting, karena bagi siswa guru dijadikan tokoh teladan (panutan), bahkan cenderung dijadikan tokoh identifikasi diri.Sebagai seorang guru yang memiliki perilaku dan kemampuan untuk mengembangkan siswa secara utuh, maka hendaknya guru menguasai berbagai hal sebagai kompetensi dasar keguruan.Jabatan guru merupakan pekerjaan profesi, oleh karena itu kompetensi guru sangatlah dibutuhkan dalam proses belajar mengajar.Guru memegang peranan dalam proses pembelajaran,dimana proses pembelajaran merupakan inti dari proses pendidikan secarakeseluruhan. Hal ini di sebabkan karena guru merupakan titik sentraldalam pembaharuan dan peningkatan mutu pendidikan, dengan kata lainsalah satu persyaratan penting bagi terwujudnya pendidikan yang bermutuadalah apabila pelaksanaannya dilakukan oleh pendidik-pendidik yangkeprofesionalannya dapat diandalkan.

Profesionalisme seorang guru berdasarkan UU No. 14 Tahun 2005 tentang Guru dan Dosen mencakup empat hal utama, yaitu: a) kompetensi pedagogik (pedagogic competency); b) kompetensi kepribadian (personality competency); c) kompetensi professional (professionalism competency); dan d) kompetensi sosial (social competency). ${ }^{1}$ Dari keempat kompetensi guru diatas, kompetensi yang berkaitan langsung dengan bidang akademis ditunjukkan oleh kompetensi pedagogik dan profesional. Kompetensi pedagogik berkaitan dengan kemampuan teknik dasar guru dalam mengelola pembelajaran, sedangkan kompetensi profesional merupakan kemampuan masing-masing guru dalam hal penguasaan substansi materi pembelajaran sesuai keahliannya. Guru yang memiliki penguasaan kompetensi pedagogik dan kompetensi profesional terefleksikan dalam proses pembelajaran di lembaga pendidikan tempat ia bekerja.

Keberhasilan penyelenggaraan tata kelola atau manajemen pendidikan sangat ditentukan olehkemampuan kepala madrasah dalam mengelola semua sumber daya yang ada dilembaganya. Hal tersebut sesuai dengan ungkapan Mulyasa bahwa,kepala sekolah

\footnotetext{
${ }^{1}$ Prayitno, Konseling Profesional yang Berhasil (Jakarta: PT. RajaGrafindo Persada,2017), 30. 
merupakan salah satu komponen pendidikan yang palingberperan dalam meningkatkan kualitas pendidikan. ${ }^{2}$ Dari pendapat tersebut, tampak jelas bahwa penentu kualitas pendidikan madrasah terletak padakemampuan manajerial kepala madrasah dalam melaksanakan tugas-tugasnya termasuk diantaranya yaitu tugas sebagai seorang supervisor dalam meningkatkan kompetensi guru. Secara umum tugas dan peran kepala madrasah memiliki lima dimensi.Dalam Permendiknas No. 13 Tahun 2007 tentangStandar Kepala Sekolah/Madrasahditegaskan bahwa, seorang kepalasekolah/madrasah harus memiliki kompetensi kepribadian, manajerial,kewirausahaan, supervisi, dan sosial. ${ }^{3}$ Seluruh kompetensi tersebut diatas mutlak harus dimiliki oleh kepala madrasah dalam rangka mewujudkan pembelajaranbermutu serta pendidikan berkualitas di lingkungan madrasahnya.

Salah satu program yang dapat diselenggarakan untuk mencapai pembelajaran danpendidikan berkualitas adalah pelaksanaan pemberian bantuan kepada guru ataulazim dikenal dengan istilah supervisi. Kepala madrasah sebagai pemimpinpendidikan di lembaganya memiliki tugas sebagai seorang supervisor. Hal ini ditegaskan olehDirjen Peningkatan Mutu Pendidik dan Tenaga KependidikanDepdiknas bahwa, tugas di bidangsupervisi merupakan tugas-tugas kepala sekolah yang berkaitan denganpembinaan guru untuk perbaikan pengajaran. ${ }^{4}$ Lebih spesifik lagi Arikunto menjelaskan bahwa, kepala sekolah lebih dekat dengan sekolah bahkan melekat pada kehidupan sekolah yang lebih banyak mengarahkan perhatiannya pada supervisi pengajaran/akademik. Kepalasekolah merupakan supervisor yang sangat tepat karena kepala sekolahlah yangpaling memahami seluk beluk kondisi dan kebutuhan sekolah yangdipimpinnya. Kepala Sekolah dituntut melakukan fungsinya sebagai manajersekolah dalam meningkatkan proses pembelajaran dengan melakukan supervisi, membina, dan memberikan saran-saran positifkepada guru. ${ }^{5}$ Selanjutnya Bafadal mengemukakan bahwa, supervisi sebagai layanan bantuan professionalkepada guru guna meningkatkan kemampuan dalam melaksanakan prosespembelajaran harus dilaksanakan secara efektif dan efisien. ${ }^{6}$

Berdasarkan uraian tersebut, dapat dilihat bahwa dalam usaha untuk memperbaiki dan meningkatkan proses pembelajaran yang dilakukan oleh guru, kepala madrasah bertugas menyelenggarakan serta melaksanakan kegiatan supervisi. Tugas ini cukup penting karena melalui peran supervisor, kepala madrasah dapat memberi bantuan, bimbingan,

${ }^{2}$ E. Mulyasa, Menjadi Kepala Sekolah Profesional (Bandung: PT. Remaja Rosdakarya,2004), 24.

3Peraturan Menteri Pendidikan Nasional Nomor 13 Tahun 2007 tentang Standar KepalaSekolah/Madrasah.

${ }^{4}$ Departemen Pendidikan Nasional, Pendidikan dan Pelatihan: Supervisi Akademik dalamPeningkatan, Profesionalisme Guru (Jakarta: Departemen Pendidikan Nasional DirektoratJenderal Peningkatan Mutu Pendidik dan Tenaga Kependidikan, 2007), 4.

${ }^{5}$ Suharsimi Arikunto, Dasar-dasar Supervisi (Jakarta: Rineka Cipta, 2004), 7.

'Ibrahim Bafadal, Peningkatan Profesionalisme Guru Sekolah Dasar dalam KerangkaManajemen Peningkatan Mutu Berbasis Sekolah (Jakarta: Bumi Aksara, 2008), 46. 
ataupun layanan kepada gurudalam menjalankan tugas ataupun dalam memecahkan permasalahan yangdihadapi pada saat proses pembelajaran.Urgensi peningkatan kompetensi dan profesionalisme guru khususnya guru di lembaga pendidikan Islam atau madrasah pada setiap jenjang saat ini sangat didorong oleh Pemerintah Pusat. Hal ini ditandai dengan diselenggarakannya program peningkatan profesionalisme guru yang mulai dikenal dengan istilah PLPG dan yang terbaru dinamai dengan Program Profesi Guru Dalam Jabatan (PPG Daljab) yang telah dimulai sejak tahun 2018 lalu yang diselenggarakan oleh 35 LPTK Perguruan Tinggi Keagamaan Islam Negeri dimana salah satunya adalah LPTK Fakultas Tarbiyah dan Keguruan (FTK) UIN Mataram. ${ }^{7}$

Hasil pantauan peneliti menunjukkan sebuah fakta menarik bahwa peningkatan kompetensi dan profesionalisme guru khususnya guru Madrasah Ibtidaiyah di Provinsi Nusa Tenggara Barat (NTB) dan Provinsi Nusa Tenggara Timur (NTT) melalui Program Profesi Guru (PPG) yang diselenggarakan oleh LPTK UIN Mataram pada tahun 2018 menunjukkan sebuah angka statistik yang cukup besar dimana jumlah pendaftar yang lolos sebagai mahasiswa peserta PPG sejumlah 520 orang. Dari jumlah tersebut, setengahnya merupakan mahasiswa peserta PPG Guru Kelas MI yaitu sejumlah 264 guru yang terbagi dalam 10 rombongan belajar, dimana 16 orang guru MI berasal dari MI se-Kabupaten Lombok Utara dan empat orang diantaranya bernaung di KKM Kecamatan Gangga Kabupaten Lombok Utara. ${ }^{8}$

Berdasarkan informasi yang diperoleh peneliti pada saat pra riset di lapangan, ditemukan sebuah fakta yang sangat menarik dan sangat inovatif dalam rangka peningkatan kompetensi guru-guru MI baik guru kelas maupun guru mata pelajaran melalui implementasi supervisi akademik kepala madrasah di KKM Kecamatan Gangga Kabupaten Lombok Utara sebagaimana diungkapkan oleh Ketua KKM bahwa, "Problematika utama yang seringkali dialami oleh kepala madrasah di Lombok Utara dalam menjalankan tugas dan tanggung jawabnya, salah satunya adalah tidak dapat berjalannya secara efektif dan efisien tentang peran kepala madrasah selaku supervisor. Hal ini terjadinya karena adanya faktor budaya yang sangat melekat dalam sistem kehidupan mereka ditambah lagi dengan adanya unsur kekeluargan dan kekerabatan sehingga semakin memperbesar rasa canggung dan tak enak hati untuk melaksanakan supervisi secara objektif dan profesional di lingkungan madrasahnya. Oleh sebab itu, untuk menanggulangi permasalahan diatas, problem solving yang telah kami rancang dan sepakati bersama yaitu strategi pelaksanaan supervisi akademik kepala madrasah dengan teknik silang atau teknik tukar peran dimana seorang kepala madrasah tidak melakukan supervisi akademik di lembaganya sendiri, melainkan

7Lihat: https:/ / www.panduanmengajar.com Daftar LPTK Penyelenggara PPGKemenag 2018, diakses tanggal 10 Juni 2019.

${ }^{8}$ Lihat: https://ppg.uinmataram.ac.id. sebaran mahasiswa guru kelas mi rombel $1 \mathrm{~s} / \mathrm{d} 10$, diakses tanggal 10 Juni 2019. 
melaksanakan supervisi akademik di madrasah lainnya yang masih bernaung di KKM yang sama." "

Lebih lanjut terkait pertimbangan logis dan akademis pemilihan latar penelitian ini di salah satu dari delapan lembaga atau satuan pendidikan MI di KKM Kec. Gangga Kab. Lombok Utara yaitu MI Riadlul Jannah NW Penjor Desa Genggelang dengan alasan sebagai berikut: 1) MI Riadlul Jannah NW Penjor saat ini berstatus sebagai Ketua Lembaga Penyelenggara KKM Kec. Gangga Kab. Lombok Utara; 2) Kepala MI Riadlul Jannah NW Penjor merupakan salah satu inisiator dan inovator dalam menyelenggarakan supervisi akademik kepala madrasah secara intensif dengan teknik tukar peran atau teknik silang di KKM Kec. Gangga Kab. Lombok Utara yang menaungi delapan lembaga madrasah; 3) Strategsi supervisi akademik kepala madrasah dengan teknik tukar peran atau teknik silang yang berlangsung di KKM Kecamatan Gangga khususnya MI Riadlul Jannah NW Penjor diyakini mampu berjalan secara objektif dan profesional dalam rangka peningkatan kompetensi guru; dan 4) Minimnya guru-guru MI yang telah bersertifikasi di MI Riadlul Jannah NW Penjor mengingat sistem seleksi yang sangat ketat, kompetitif dan kuota terbatas, sehingga hal ini memubutuhkan peran seorang kepala madrasah selaku supervisor untuk meningkatkan kualitas lembaga pendidikannya.

Berangkat dari uraian latar belakang permasalahan diatas, maka peneliti sangat tertarik untuk mengadakan sutu penelitian dengan judul: "Strategi Peningkatan Kompetensi Guru melalui Supervisi Akademik Kepala Madrasah (Studi Kasus di MI Riadlul Jannah NW Penjor Desa Genggelang Kecamatan Gangga Kabupaten Lombok Utara)”

\section{METODE PENELITIAN}

Pendekatan yang digunakan dalam penelitian ini adalah pendekatan kualitatif. Menurut Bogdan dan Taylor sebagaiman dikutip oleh Lexy J. Moleong mendefinisikan bahwa metodologi kualitatif sebagai prosedur penelitian yang menghasilkan data deskriptif berupa kata-kata tertulis atau lisan dari orang-orang dan perilaku yang dapat diamati. Penelitian yang menggunakan pendekatan kualitatif memiliki enam jenis penelitian yaitu: etnografis, fenomenologi, studi kasus, grounded theory, deskriptif, dan biografi. Berdasarkan fokus permasalahan dalam penelitian ini dan mengikuti saran Stake dalam John W. Creswell, maka peneliti menggunakan jenis penelitian studi kasus.Menurutnya studi kasus merupakan strategi penelitian dimana di dalamnya peneliti menyelidiki secara cermat suatu program, peristiwa, aktivitas, proses, atau sekelompok individu.Kasus-kasus dibatasi oleh waktu dan aktivitas, dan peneliti mengumpulkan informasi secara lengkap dengan menggunakan berbagai prosedur pengumpulan data berdasarkan waktu yang telah ditentukan.

\footnotetext{
'Slamet Riyadi, Kepala MI Riyadlul Jannah NW Penjor Desa Genggelang sekaligus Ketua KKM Kecamatan Gangga Kabupaten Lombok Utara, Wawancara (Gangga, 12 Juni 2019). 
Alasan peneliti menggunakan pendekatan kualitatif karena: Pertama, penelitian ini berusaha menyajikan langsung hakikat hubungan antara peneliti dan responden atau informan dengan tujuan supaya lebih peka dalam menyesuaikan diri terhadap pola-pola nilai yang dihadapi ketika di lapangan; Kedua, data dalam penelitian ini dikumpulkan melalui observasi, wawancara mendalam dan analisis dokumen. Fakta-fakta dikumpulkan secara lengkap, selanjutnya ditarik kesimpulan.Kasus yang diteliti adalah strategi supervisi kepala madrasah dengan teknik silang atau tukar peran sebagai point of view pada lembaga pendidikan yang diteliti. Rancangan studi kasus dilakukan sebagai upaya pertanggungjawaban ilmiah berkenaan dengan keterkaitan logis antara fokus penelitian, pengumpulan data yang relevan, dan analisis data hasil temuan. Penerapan rancangan studi kasus ini akan dimulai dengan melakukan pengumpulan data pada kasus di MI Riadlul Jannah NW Penjor Desa Genggelang Kecamatan Gangga Kabupaten Lombok Utara.

Kehadiran peneliti di lapangan dalam kajian ini bersifat mutlak. Peneliti berstatus sebagai instrumen utama (key instrument) tanpa mewakilkan kehadirannya pada orang lain. Kehadiran peneliti bertujuan untuk melakukan pengamatan dan wawancara mendalam guna mendapatkan data akurat dari informan yang diperlukan peneliti untuk melengkapi data penelitian.Salah satu ciri khas dalam penelitian yang bersifat kualitatif adalah tidak terpisahkan dari proses pengamatan pera serta (participant-observation) peneliti, sebab peranan seorang peneliti sangat menentukan keseluruhan skenarionya. Untuk itu, peneliti bertindak sebagai key instrument, partisipan penuh serrta pengumpul data lapangan, sedangkan instrumen lainnya hanya bersifat sebagai penunjang.

Ditinjau dari cara memperolehnya, data dapat dikelompokkan menjadi dua macam, yaitu data primer dan data sekunder. Dalam hal ini, data primer adalah data yang diperoleh dan dikumpulkan secara langsung dari para informan melalui hasil pengamatan, catatan lapangan dan interview. Sedangkan data sekunder adalah data yang sudah diolah dalam bentuk naskah tertulis atau dokumen yang diperoleh di lokasi penelitian sebagai data pendukung dari kegiatan penelitian yang dilakukan.Menurut Lofland sebagaimana dikutip oleh Moleong menuliskan bahwa sumber data utama (data primer) dalam penelitian kualitatif ialahberupa kata-kata, dan tindakan, dan selebihnya adalah data tambahan (data sekunder) seperti dokumen dan lain-lain. Sumber data dalam penelitian terbagi menjadi tiga kategori yaitu: 1) kata-kata dan tindakan; 2) sumber tertulis; dan 3) foto yang terdeskripsikan dalam catatan lapangan. Kata-kata atau ungkapan lisan yang berasal dari para informan yang telah dipilih oleh peneliti meliputi: (1) Kepala MI Riadlul Jannah NW Penjor Desa Genggelang selaku supervisor serta Ketua KKM Kecamatan Gangga Kabupaten Lombok Utara; (2) Para Kepala Madrasah lainnya di KKM Kecamatan Gangga yang bertugas melakukan supervisi di MI Riadlul Jannah NW Penjor Desa Genggelang; dan (3) Guru-guru MI Riadlul Jannah NW Penjor Desa Genggelang baik yang berstatus sebagai guru kelas maupun guru mata pelatan yang telah mendapatkan supervisi akademik dari 
supervisor. Sedangkan sumber-sumber tertulis yang meliputi arsip seperti: dokumen program kerja supervisi kepala MI, maupun perangkat pembelajaran guru MI pasca supervisi, maka peneliti pergunakan sebagai bahan analisis data sebagaimana termuat dalam lampiran.

Dalam tahap pelaksanakan penelitian khususnya pengambilan data yang dilakukan secara langsung di lapangan, maka penulis mengungkapkan data menggunakan catatan lapangan melalui teknik pengamatan, wawancara, dan penggunaan dokumen. Dalam proses pengamatan (observasi) di lapangan, peneliti sebagai seorang pengamat juga bersifat terbuka (open minded) dan diketahui oleh subjek penelitian ataupun oleh informan (transparant), pun sebaliknya para subjek atau informan dengan sukarela memberikan kesempatan kepada pengamat untuk mengobservasi peristiwa yang terjadi di lapangan. Adapun data yang ingin diperoleh peneliti melalui kegiatan pengamatan atau observasi ini antara lain sebagai berikut: 1) Kepala MI Riadlul Jannah NW Penjor Desa Genggelang selaku Ketua KKM tingkat MI se-Kecamatan Gangga Kabupaten Lombok Utara meliputi kegiatan perencanaan, pengorganisasian, pelaksanaan dan evaluasi supervisi akademik; 2) Kepala madrasah lainnya di KKM tingkat MI se-Kecamatan Gangga Kabupaten Lombok Utara yang bertugas sebagai supervisor di MI Riadlul Jannah NW Penjor Desa Genggelang dalam melaksanakan kegiatan supervisi; 3) Para guru MI Riadlul Jannah NW Penjor Desa Genggelang baik guru kelas maupun guru mata pelajaran mengenai kegiatan supervisi yang dihasilkannya berupa perangkat pembelajaran maupun proses pembelajaran; dan 4) Kondisi lingkungan MI Riadlul Jannah NW Penjor Desa Genggelang serta sarana prasarana pendukung pembelajaran yang tersedia.

Adapun data yang ingin diperoleh peneliti dari para informan melalui kegiatan wawancara semi terstruktur ini antara lain sebagai berikut: 1) Kepala MI Riadlul Jannah NW Penjor Desa Genggelang selaku Ketua KKM tingkat MI se-Kecamatan Gangga Kabupaten Lombok Utara mengenai kegiatan manajemen supervisi meliputi perencanaan, pengorganisasian, pelaksanaan dan evaluasi supervisi akademik; 2) Kepala madrasah lainnya di KKM tingkat MI se-Kecamatan Gangga Kabupaten Lombok Utara yang bertugas sebagai supervisor di MI Riadlul Jannah NW Penjor Desa Genggelang dalam melaksanakan kegiatan supervisi akademik meliputi: strategi supervisi akademik kepala madrasah teknik silang atau tukar peran, hambatan yang dihadapi dan solusi yang ditawarkan, serta implikasi supervisi akademik bagi lembaga dan guru yang bersangkutan; dan 3) Para guru MI Riadlul Jannah NW Penjor Desa Genggelang baik guru kelas maupun guru mata pelajaran mengenai kegiatan supervisi yang dihasilkannya berupa kemampuan membuat perangkat pembelajaran serta pelaksanaan proses pembelajaran.Selanjutnya teknik dokumentasi digunakan untuk mendapatkan sejumlah data pendukung seperti: dokumentasi profil MI Riadlul Jannah NW Penjor Desa Genggelang sebagai Ketua Lembaga Penyelenggara KKM Kecamatan Gangga Kabupaten Lombok Utara, dokumentasi pelaksanaan supervisi oleh 
kepala madrasah dan guru-guru bersangkutan, serta data dokumentasi lainnya yang relevan dengan penelitian ini.

Sesuai dengan jenis penelitian di atas, peneliti menggunakan model interaktif dari Miles, Huberman dan Saldana dalam proses analisis data hasil penelitian. Aktivitas analisis data dilaksanakan secara interaktif dan berjalan terus-menerus hingga tuntas sampai kejenuhan data tercapai. Komponen-komponen analisis data model interaktif tersebut terdiri dari reduksi data, displai data, dan verifikasi atau pengambilan kesimpulan. Sedangkan proses pengecekan keabsahan data atau uji validitas data pada penelitian ini dilakukan melalui beberapa teknik di antaranya: perpanjangan keikutsertaan peneliti, ketekunan pengamatan, triangulasi dan pemeriksaan sejawat melalui diskusi. Dari keempat teknik validitas data tersebut, peneliti menggunakan dua teknik dalam penelitian ini yaitu teknik ketekunan pengamatan dan triangulasi khususnya triangulasi dengan sumber.

\section{HASIL DAN PEMBAHASAN}

Analisis Urgensi Pelaksanaan Supervisi Akademik Para Kepala Madrasah Anggota KKM dalam Peningkatan Kompetensi Pedagogik dan Profesional bagi Guru MI Riadlul Jannah NW Penjor

Urgensi pelaksanaan supervisi akademik oleh para kepala madrasah anggota KKM MI se-Kecamatan Gangga Kabupaten Lombok Utara, dimana salah satunya adalah MI Riadlul Jannah NW Penjor merupakan kesepakatan atau persetujuan bersama yang telah disetujui oleh seluruh anggota KKM dan ditetapkan sebagai sebuah program KKM bersama. Pelaksanaan supervisi akademik ini dimasin-masing MI berangkat dari hasil analisis kebutuhan guru dan masing-masing madrasah untuk peningkatan profesionalisme guru yang lebih baik. Analisis kebutuhan peningkatan profesionalisme tersebut antara lain: a) latar belakang pendidikan guru dengan tugasnya sebagai guru berbeda; b) kurangnya kemampuan guru dalam menerapkan metode belajar yang efektif; c) kurangnya inisiatif guru secara mandiri untuk meningkatkan kemampuannya dalam mengajar; d) gaya guru yang monoton yang menimbulkan rasa kebosanan bagi siswa, e) pengetahuan guru yang terbatas dalam memahami tingkah laku siswa, dan f) ketersediaan fasilitas yang kurang lengkap di madrasah serta keterbatasan alat penunjang pembelajaran.

Untuk menindaklanjuti program supervisi akademik tersebut, solusi terbaik yang perlu diperhatikan oleh para kepala madrasah anggota KKM MI antara lain: merekrut dan menempatkan posisi guru dalam mengajar yang sesuai dengan latar belakang keilmuannya dan kualifikasi pendidikannya, memberikan pemahaman kepada guru baik di dalam rapat maupun pada pertemuan lainnya bahwa kemampuan guru yang baik sangat berdampak pada tingkat pemahaman siswa yang baik pula, dan memfasilitasi guru dalam menerapkan pola belajar yang kreatif dengan tetap menganggarkan pengadaan sarana prasarana pendukung pembelajaran secara bertahap dan berkelanjutan. 
Selain itu, sejumlah faktor yang menjadi penghambat bagi guru baik guru kelas maupun guru mata pelajaran dalam meningkatkan kompetensi pedagogik dan profesionalnya sehingga program supervisi akademik menjadi begitu penting dilaksanakan di MI Riadlul Jannahw NW Penjor antara lain sebagai berikut.

\section{Keadaan motivasi guru yang tidak stabil}

Tingkat motivasi guru yang tidak stabil atau naik turun ini sangatlah manusiawi terjadi pada diri guru.Namun solusi yang dapat diberikan kepada guru adalahmotivasi yang harus selalu disampaikan oleh kepala madrasah di setiap kesempatan dengan melakukan pembinaan dan memberikan penghargaan serta memupuk rasa ingin belajar guru secara terus menerus dan berkelanjutan. Selain itu kepala madrasah harus mendorong para guru untuk mengikuti kegiatan seminar, workshop, pelatihan-pelatihan relevan lainnya, kegiatan MGMP, kegiatan KKG dan kegiatan sejenis lainnya.

\section{Kurangnya koordinasi antara guru dan kepala madrasah}

Koordinasi yang kurang efektif antara guru dengan kepala madrasah dapat menghambat pelaksanaan kegiatan. Tujuan mengadakan koordinasi tersebut yaitu untuk membahas tentang bagaimana bentuk pelaksanaan dari kegiatan yang akan dilaksanakan. Apabila sudah terencana dan diprogram maka kegiatan tersebut akan terlaksana dengan maksimal.

\section{Keterbatasansarana prasarana pembelajaran}

Sarana prasarana pendukung pembelajaran yang terbatas merupakan salah satu faktor penghambat yang paling sering terjadi di madrasah swasta, termasuk MI Riadlul Jannah NW Penjor Desa Genggelang Kecamatan Gangga Kabupaten Lombok Utara. Solusi yang dapat coba dirumuskan bersama adalah mencoba untuk terus memperbaiki sarana yang ada, sedikit demi sedikit terus dianggarkan dalam setiap rancangan anggaran kegiatan madrasah, karena hal ini sangat mendukung kemajuan pendidik dan madrasah.

\section{Analisis Implementasi Supervisi Akademik Kepala Madrasah melalui Teknik Tukar Peran dalam Peningkatan Kompetensi Pedagogik dan Profesional Guru MI Riadlul Jannah NW Penjor}

\section{Perencanaan Program Supervisi Akademik di MI Riadlul Jannah NW Penjor}

Konsep perencanaan dalam perspektif agama Islam terlihat jelas dalam proses penciptaan langit dan bumi beserta segala isinya bahwa Allah Swt. telah merencanakan segala sesuatu dengan jelas dan matang bahkan usia manusia pun telah direncanakan panjang pendeknya. Dalam al-Qur'an, manusia diperintahkan untuk memperhatikan dan mempersiapkan bekalnya untuk menyongsong kehidupan sejati di akhirat. Hal ini sebagai termuat dalam Q.S. Al-Hasyar [59]: 18 sebagai berikut: 
"Hai orang-orang yang beriman, bertakwalah kepada Allah dan hendaklah Setiap diri memperbatikan apa yang telah diperbuatnya untuk hari esok (akbirat); dan bertakwalab kepada Allah, Sesunggubnya Allah Maha mengetahui apa yang kamu kerjakan". ${ }^{10}$

Perencanaan (planning) merupakan kegiatan awal dalam sebuah pekerjaan melalui bentuk pemikiran akan hal-hal terkait dengan pekerjaan tersebut agar mendapatkan hasil yang maksimal dan optimal, serta tidak terjadi dengan sia-sia. ${ }^{11}$ Dalam hal ini, firman Allah Swt. dalam Q.S. Shad [38]: 27 juga memperkuat prinsip perencanaan, yaitu:

"dan Kami tidak menciptakan langit dan bumi dan apa yang ada antara keduanya tanpa bikmah. yang demikian itu adalah anggapan orang-orang kafir, Maka celakalah orang-orang kafir itu karena mereka akan masuk neraka". ${ }^{12}$

Banyak teori mengatakan bahwa merencanakan pekerjaan dengan baik dan matang berarti $60 \%$ program tersebut telah selesai dilaksanakan, demikian strategisnya arti sebuah perencanaan. Bahkan dalam sebuah hadits yang diriwayatkan oleh Ibnul Mubarak yang dikutip dari Didin Hafidhuddin dan Hendri Tanjung menyebutkan bahwa: "Islam menyuruh ummatnya untuk menggagalkan suatu kegiatan bila dalam kajian perencanaannya terdapat indikasi berakibat buruk atau mendatangkan mudharat bagi pelakunya." ${ }^{\text {13 }}$

Sedangkan supervisi ditinjau dari perspektif Al-Qur'an merupakan suatu bentuk pengawasan menjadi sesuatu yang sangat strategis sekali apabila setiap supervisor dalam suatu organisasi atau lembaga tersebut telah menyadari urgensinya sehingga penyimpangan dapat terhindari.Namun perlu digarisbawahibahwa nilai-nilai Islam mengajarkan secara mendasar mengenaipengawasan tertinggi atas perbuatan dan usaha manusia baik secaraindividu maupun secara organisatoris adalah Allah Swt. Pengawasan dariAllah Swtterletak pada sifat Allah Yang Selalu Menjaga dan Mengawasi manusia.Allah telah menegaskannya dalam QS. Al-Fajr [89] ayat 14 sebagaik berikut.

"Sesunggubnya Tuhanmu benar-benar mengawasi." "14

Dari terjemahan ayat di atas dapatlah dipahami bahwa Allah Swt bersifat selalu mengawasi perbuatan hamba-hamba-Nya agar tidak melenceng dari syari'at yang telah ditetapkan. Begitup pula halnya profesi guru agar dapat berjalan sesuai dengan aturan standar operasional prosedur, maka dibutuhkan seorang supervisor atau pengawas yang selalu mengawasi dan menyaksikan sendiri kinerja para guru serta berupaya untuk meluruskan penyimpangan-penyimpangan yang kemungkinan besar terjadi yang dilakukan oleh guru yang diawasinya sehingga tujuan bersama yang telah ditetapkan dapat tercapai.

\footnotetext{
${ }^{10}$ Departeman Agama RI - Yayasan Penyelenggara Penterjemah/Pentafsir Al-Qur'an, Al-Qur'an, 455.

${ }^{11}$ Didin Hafifuddin dan Hendri Tanjung, Manajemen Syariah dalam Praktek Jakarta: Gema Insani, 2003), 77.

${ }^{12}$ Departeman Agama RI - Yayasan Penyelenggara Penterjemah/Pentafsir Al-Qur'an, Al-Qur'an, 548.

${ }^{13}$ Hafifuddin dan Tanjung, Manajemen Syari'ah, 77.

${ }^{14}$ QS. Al-Fajr [89]: 14.
} 
Perencanaan program supervisi akademik oleh Kepala MI Riadlul Jannah NW Penjor yang melibatkan para kepala madrasah anggota KKM MI se-Kecamatan Gangga sebagai supervisor bagi dewan guru baik guru kelas maupun guru mata pelajaran di MI Riadlul Jannah NW Penjor yang disupervisi diharapkan dapat meningkatkan kinerja dan profesionalismenya. Perencanaan program supervisi adalah penyusunan dokumen perencanaan pemantauan serangkaian kegiatan membantu guru mengembangkan kemampuannya mengelola proses pembelajaran untuk mencapai tujuan pembelajaran. ${ }^{15}$ Hasil penelitian ini menunjukkan bahwa perencanaan supervisi akademik oleh kepala MI Riadlul Jannah NW Penjor bersama-sama dengan para kepala madrasah lainnya di KKM yang sama dalam mengembangkan kompetensi pedagogik dan kompetensi profesional guru di MI Riadlul Jannah NW Penjor sudah terencana dengan baik yang diawali dengan kegiatan rapat perencanaan yang diselenggarakan di awal tahun pembelajaran di saat siswa sedang libur sekolah.

Perencanaan lanjutan dalam supervisi akademik yang dilakukan oleh Kepala MI Riadlul Jannah NW Penjor adalah melibatkan guru dalam menyampaikan program supervisi yang telah disepakati melalui kegiatan rapat KKM terkait dengan program supervisi akademik. Dalam kegiatan rapat dengan dewan guru tersebut, kepala madrasah kepada semua dewan guru bisa memahami dan bisa mempersiapkan diri. Selain itu, kepala madrasah juga menyampaikan tentang maksud dan tujuan diadakannya supervisi akademik.

\section{Pelaksanaan Program Supervisi Akademik di MI Riadlul Jannah NW Penjor}

Kegiatan pelaksanaan supervisi akademik di MI Riadlul Jannah NW Penjor secara garis besar terbagi menjadi dua hal yaitu: kegiatan awal berupa penyusunan perangkat pembelajaran dari semua guru yang akan disupervisi dan dikoreksi oleh supervisor, dan kegiatan selanjutnya adalah kegiatan supervisi yang berlangsung di dalam kelas sesuai dengan jadwal yang telah ditetapkan dan ditentukan bersama pada saat rapat perencanaan. Lebih jelasnya jenis dua kegiatan tersebut dipaparkan sebagai berikut.

\section{a. Tahap Pengumpulan Perangkat Pembelajaran Pra Supervisi}

Beberapa komponen atau perangkat pembelajaran kurikulum 2013 yang wajib dikumpulkan oleh masing-masing guru yang akand disupervisi dalam rangka mensukseskan kegiatan supervisi akademik antara lain: silabus, program tahunan (prota), program semester (prosem), rencana program pembelajaran (RPP) beserta instrumen penilaiannya, ringkasan materi bahan ajar, penggunaan metode dan penyiapan media pembelajaran, dan sejenisnya. Setelah semua komponen perangkat pembelajaran tersebut terkumpul, maka kepala MI Riadlul Jannah NW Penjor menandatangani dan menyerahkannya kepada para supervisor untuk dikoreksi dan diberikan penilaian. 2012), 59.

${ }^{15}$ Abdul Kadim Masaong, Supervisi Pembelajaran dan PengembanganKapasitas Guru(Bandung: Alfabeta, 


\section{b. Tahap Pelaksanaan Supervisi Akademik}

Pelaksanaan supervisi akademik yang berlangsung di MI Riadlul Jannah NW Penjor yang dijalankan oleh supervisor dan diikuti oleh guru yang disupervisi melalui kunjungan kelas sesuai jadwal yang telah dibuat. Pelaksanaan yang dilakukan supervisor sebanyak dua kali dalam semester yaitu di pertengahan semester dan di akhir semester. Pelaksanaan supervisi yang dilakukan oleh supervisor dapat membantu para guru dalam mempersiapkan segala sesuatu yang berkaitan dengan proses belajar mengajar di kelas. Dengan adanya kegiatan supervisi ini sangat membantu para guru untuk mengetahui letak kekurangan dan kelebihan dirinya dalam menyiapkan suatu program pembelajaran, karena pada dasarnya supervisi ini gunanya adalah bantuan yang diberikan kepala madrasah dalam mengembangkan profesionalisme guru.

Dalam pandangan Glickman, dinyatakan bahwa tujuan supervisi akademik dapat membantu guru dalam tiga hal mendasar antara lain: a) mengembangkan kompetensinya; b) mengembangkan kurikulum; dan c) mengembangkan Kelompok Kerja Guru serta membimbing Penelitian Tindakan Kelas (PTK).Dalam melaksanakan program supervisi akademik, maka supervisor terlebih dahulu mempersiapkan strategi, pendekatan serta teknik yang dijalankan dalam melakukan tugasnya di kelas. Dari hasil pengamatan peneliti di lapangan, bahwa pendekatan yang digunakan oleh oleh supervisor sebagaian besar hanya menggunakan satu pendekatan yaitu pendekatan secara langsung. Namun ada beberapa supervisor yang menggunakan dua pendekatan sekaligus dalam pelaksanaan supervisi akademiknya, yaitu pendekatan secara langsung dan pendekatan tidak langsung.

Sebagaimana yangdijelaskan oleh Piet A. Sahertian bahwa, pendekatan langsung merupakan cara pendekatanterhadap masalah yang bersifat langsung. Supervisor memberikan arahanlangsung.Sudah tentu pengaruh perilaku supervisor lebih dominan.Pendekatan langsung atau pendekatan direktif ini berdasarkan pemahaman terhadap psikologibehaviorisme. Prinsip behaviorisme ialah bahwa segala perbuatan berasal darirefleks, yaitu respons terhadap rangsangan/stimulus. Oleh karena guru inimengalami kekurangan, maka perlu diberikan rangsangan agar ia biasbereaksi. Supervisor dapat menggunakan penguatan atau hukuman.Pendekatan seperti ini dapat dilakukan dengan perilaku supervisor denganmenjelaskan, menyajikan, mengarahkan, memberi contoh, menetapkan tolokukur, dan menguatkan. ${ }^{16}$

Namun pada hal-hal tertentu, beberapa para kepala madrasah anggota KKM MI seKecamatan Gangga selaku supervisordi MI Riadlul Jannah NW Penjor juga menerapkan pendekatan secara tidak langsung.Sebagaimana dari hasil wawancara dengan salah seorang supervisor yang menjelaskan bahwa hal-hal tertentu yang sangat sensitif dan menyangkut privasi guru yang sifatnya kurang etis untuk didengar atau disaksikan oleh guru lainnya maupun oleh para siswanya di dalam kelas, maka solusi terbaik dan etis untuk diberikan

16Piet A. Sahertian, Konsep Dasar Supervisi Pendidikan (Jakarta: Rineka Cipta 2000), 51. 
arahan secara personal adalah dengan cara memanggil guru yang bersangkutan kekantor kepala dan selanjutnya secara empat mata diberikan arahan, masukan, dan motivasi secara tertutup, jadi tidak disampaikan di hadapan orang banyak yang dapat menyebabkan pembunuhan karakter bagi guru yang bersangkutan.

Pendekatan secara tidak langsung ini sangat sesuai dengan teori yang disampaikan Piet A. Sahertian bahwa pendekatan yang sifatnya tidak langsung dimana perilaku yang ditunjukkan oleh kepala sekolah selaku supervisor dengan terlebih dulu mendengarkan secara aktif apa yang dikemukakan oleh guru. selanjutnya guru diberikan kesempatan menjelaskan problematikanya, setelah kepala sekolah memahami akar permasalahan tersebut barulah kemudian kepala sekolah memberi arahan terhadap guru tersebut. ${ }^{17}$ Dalam kalimat lain, seorang supervisor berperan sebagai konsultan yaitu dapat memberi bantuan bersama mengkonsultasikan masalah yang dialami guru secara individu maupun kelompok, karena seorang supervisor selain berfungsi sebagai evaluator kegiatan pembelajaran di lembaganya, juga sebagai konsultan yang dapat membantu masalah pribadi. Dari uraian tersebut dapat peneliti simpulkan bahwa pendekatansupervisi yang digunakan oleh para supervisor di MI Riadlul Jannah NW Penjor dalam pelaksanaan program supervisi akademik untuk meningkatkan kompetensi pedagogik dan profesional guru adalah dengan menggunakan pendekatan langsung dantidak langsung, namun lebih dominan pada pendekatan langsung.

Selanjutnya dalam hal teknik supervisi akademik, dua jenis teknik yang seringkali digunakan oleh para supervisor, yaitu teknik individual dan teknik kelompok. Namun, seluruh supervisor di MI Riadlul Jannah NW Penjor dalam melaksanakan tugas supervisi akademik menggunakan jenis teknik yang pertama yaitu teknik individual atau seringkali juga dikenal dengan istilah teknik perseorangan. Teknik individual yang dijalankan terdiri dari beberapa model antara lain: kunjungan kelas, observasi kelas, dan pertemuan individu sebagaimana dijelaskan sebagai berikut.

\section{a. Kunjungan kelas}

Dalam melaksanakan tugas supervisi, para supervisor di MI Riadlul Jannah NW Penjor melakukan kunjungan kelas untuk dapat menyaksikan langsung proses guru mengajar di kelas menyampaikan materi kepada siswa dan juga memberikan arahan kepada guru dalam proses pembelajaran. Pelaksanaan kunjungan kelas yang ideal oleh seorang supervisor yaitu minimal sebulan sekali dalam rangka supervisi akademik.Hal tersebut senada dengan apa yang disampaikan oleh Burhanudin, bahwa kunjungan kelas ialah kegiatan kunjungan sewaktu-waktu yang dilakukan oleh supervisor (kepala sekolah, penilik, atau pengawas) untuk melihat atau mengamati pelaksanaan proses pembelajaran sehingga diperoleh data untuk tindak lanjut dalam pembinaan selanjutunya. Teknik ini berfungsi

${ }^{17}$ Sahertian, Konsep Dasar Supervisi Pendidikan, 51. 
untuk mengoptimalkan cara belajar mengajar yang dilaksanakan para guru dan membantu mereka untuk menumbuhkan profesi kerja secara optimal. ${ }^{18}$

Melalui kegiatan kunjungan kelas dalam pelaksanaan supervisi akademik, maka seorang kepala madrasah selaku supervisor dapat membantu guru dalam hal kegiatan belajar mengajar yaitu bagaimana cara menyampaikan materi, menggunakan metode mengajar yang bervariasi dan disesuaikan dengan materi dan membantu menggunakan media yang baik dan relevan agar peserta didik mudah memahami materi pelajaran. Hal ini sesuai dengan yang diungkapkan oleh Sahertian mengenai komponen dalam menganalisis situasi proses belajar mengajar yaitu: (1) Membantu guru dalam kaitannya dengan tujuan pendidikan, (2) Membantu guru agar lebih mampu membimbing pengalaman belajar dan keaktifan belajar murid. (3) Membantu guru dalam menerapkan metode dan teknik mengajar yang lebih berdaya guna.

\section{b. Observasi kelas}

Dalam proses kunjungan kelas oleh kepala madrasah selaku supevisor, maka hal yang dilakukannya adalah dengan cara memperhatikan kegiatan yang dilakukan oleh guru pada saat mengajar, penyampaian materi, penguasaan kelas sehingga anak-anak dapat memperhatikan dan termasuk penggunaan media pembelajaran. Hal tersebut sesuai dengan apa yang disampaikan oleh Burhanudin bahwa observasi kelas merupakan teknik observasi yang dilakukan ketika supervisor yang secara aktif mengikuti jalannya kunjungan kelas ketika proses pembelajaran sedang berlangsung. Hal ini bertujuan untuk memperoleh data yang subjektif mengenai aspek situasi dalam proses pembelajaran yang diamati. ${ }^{19} \mathrm{Hal}$ senada juga disampaikan oleh Piat A. Sahertia bahwa dalam pelaksanaan teknik observasi kelas, maka sejumlah aspek yang dapat diobservasi antara lain: usaha dan aktifitas kegiatan guru siswa pada saat berlangsungnya proses pembelajaran, penggunaan media pembelajaran oleh guru, reaksi mental para peserta didik dalam mengikuti proses pembelajaran, lingkungan sosial, keadaan fisik sekolah, baik di dalam maupun di luar kelas dan faktorfaktor penunjang lainnya. ${ }^{20}$

\section{c. Pertemuan individu}

Dalam menjalankan kegiatan supervisi akademiknya, maka kepala madarasah selaku supervisor juga dapat menerapkan pertemuan individu dengan guru yang disupervisinya yang melakukan kebetulan melakukan sejumlah kesalahan atau menjalankan tugasnya kurang baik dengan cara menemui saat di kelas, memanggil guru tersebut ke ruang kepala madrasah maupun secara langsung saat kepala madrasah melihat suatu tindakan kesalahan dari guru. Selanjutnya kepala madrasah selaku supervisor dapat memberikan penjelasan dan pengarahan serta masukan terkait dengan kesalahan yang dilakukan oleh guru tersebut.Hal 329.

${ }^{18}$ Burhanuddin, Analisi Administrasi Manajmen dan Kepemimpinan Pendidikan (Jakarta: BumiAksara, 1994),

${ }^{19}$ Ametembun, Supervisi Pendidikan (Bandung: IKIP Bandung, 1975), 65.

${ }^{20}$ Piet A. Sahertian, Konsep Dasar dan Teknik Supervisi Pendidikan (Jakarta: Rineka Cipta,2000), 57. 
ini sesuai dengan teori bahwa teknik pertemuan individu ini memiliki 3 jenis yaitu: a) Classroom Conference, yaitu kegiatan percakapan di kelas ketika para peserta didik tidak berada di dalam kelas; b) Office Conference,yaitu kegiatan percakapan yang dilakukan di ruang kepala sekolah atau ruang guru; dan c)Casual Conference, yaitu kegaiatan percakapan yang dlaksanakan secara kebetulan.

\section{Evaluasi Supervisi Akademik di MI Riadlul Jannah NW Penjor}

Evaluasi merupakan sekumpulan informasi yang diperoleh oleh seseorangsebelum memberikan hasil penilaian dari informasi tersebut. Hasil evaluasi pada program supervisi akademik berperan penting dalam memberikan solusi konstruktif bagi guru dalam menghadapi problematika yang dialaminya dalam melaksanakan tugas keprofesioannya. Evaluasi supervisi akademikdapat dijadikan sebagai instrumen pembantu untuk melihat sejauhmana kualitas kinerja seorang guru, selanjutnya hasil evaluasi tersebut menjadi bahan masukan (entry point) bagi guru untuk mengembangkan kinerja dan profesionalismenya.

Dari hasil penelitian baik melalui wawancara maupun observasi dapat disimpulkan bahwa proses evaluasi supervisi akademik di MI Riadlul Jannah NW Penjor yang dilakukan para supervisor dapat dikatakan sudah terlaksana dengan baik. Evaluasi ini bertujuan untuk mengetahui dan mendalami sampai sejauhmana tingkat penguasaan kompetensi seorang guru atau sampai sejauhmana kualitas seorang guru dalam menjalankan tugas profesinya sebagai pendidik.Menurut pendapat Bloom, evaluasi merupakan pengumpulan kenyataan secara sistematis untuk menetapkan apakah dalam kenyataannya terjadi perubahan dalam diri siswa dan menetapkan sejauh mana tingkat perubahan dalam pribadi siswa atau tidak. ${ }^{21}$ Dari penjelasan di atas dapat disimpulkan bahwa evaluasi merupakan hal yang sangat penting untuk dilakukan, karena evaluasi terhadap kegiatan supervisi akademik yang dilakukan kepala madrasah selaku supervisor memberikan dampak yang positif. Dengan adanya program supervisi akademik, maka supervisor dapat membantu para guru mengembangkan sifat profesionalnya, dimana hal ini dapat dilihat dari perubahan cara guru mengajar atau perubahan yang dialami oleh peserta didiknya ke arah yang lebih baik.

Setelah evaluasi dilakukan oleh seorang supervisor, maka ia harus melakukan tindak lanjut dengan cara memberikan sejumlah rekomendasi kepada guru binaannya. Kepala madrasah selakuk supervisor dapat melakukannya dengan berbagai cara, misalnya dengan mengadakan kegiatan In-service Training, penataran, workshop, seminar, pertemuan guru, MGMP, dan lain sebagainya. Hal ini sebagaimana diungkapkan oleh Piet A. Sahertian sesuai dengan fungsi utama supervisi yaitu ditujukan pada perbaikan dan peningkatan kualitas pengajaran. ${ }^{22}$ Kegiatan ini dimaksudkan untuk meningkatkan keahlian guru guna

\footnotetext{
${ }^{21}$ SitiAtava Rizma Putra, Desain Evaluasi Belajar Berbasis Kinerja(Yogyakarta: Diva Press, 2013), 73.

${ }^{22}$ Sahertian, Konsep Dasar dan Teknik Supervisi, 21.

Copyright (C2020 Schemata Journal

Available online at http:/ /journal.uinmataram.ac.id/index.php/schemata
} 
menyelaraskan pengetahuan dan ketrampilan mereka khususnya untuk meningkatkan mutu pendidikan.Kegiatan ini bisa dilakukan dengan kelompok maupun individu.

\section{Analisis Implikasi Supervisi Akademik Kepala Madrasah Teknik Tukar Peran bagi MI Riadlul Jannah NW Penjor}

Strategi para supervisor dalam mengembangkan kompetensi pedagogik dan kompetensi profesional guru di MI Riadlul Jannah NW Penjor memiliki dampak yang signifikan baik bagi lembaga atau madrasah pada umumnya maupun secara khusus bagi guru yang disupervisi. Hal ini dapat dijelaskan sebagai berikut.

\section{Implikasi bagi Lembaga Madrasah}

Penerapan strategi supervisi akademik oleh para supervisor dalam mengembangkan kompetensi pedagogik dan profesional bagi guru di MI Riadlul Jannah NW Penjor memiliki implikasi yang sangat positif bagi pengembangan lembaga atau madrasah. Dengan terlaksananya supervisi akademik dengan baik dan lancar, maka akan terlihat jelas seperti apa kelebihan dari sumber daya yang dimiliki oleh madrasah dan seperti apa juga kekurangan-kekurangan yang perlu segera diatasi.Lebih jelasnya, implikasi atau dampak yang bisa dirasakan oleh lembaga MI Riadlul Jannah NW Penjor melalui kegiatan supervisi akademik oleh para kepala madrasah selaku supervisor se-KKM MI Kecamtan Gangga Kabupaten Lombok Utara dapat dijabarkan sebagai berikut.

\section{a. Madrasah dapat mengkoordinasi semua upaya peningkatan kualitas lembaga} secara terkoordinir.

Upaya-upaya ini meliputi: 1) Upaya setiap guru yaitu setiap guru diberi kesempatan untuk mengemukakan idenya dan menguraikan materi pelajaran menurut pandangannya kearah peningkatan yang lebih baik; 2) Upaya madrasah dalam hal menentukan kebijakan, merumuskan tujuan-tujuan atas setiap kegiatan madrasah termasuk program-program sepanjang tahun ajaran perlu ada koordinasi yang baik; 3) Usaha-usaha bagi pertumbuhan jabatan melalui berbagai bentuk kegiatan melalui service training, extension course, workshop, seminar guru-guru, selalu berusaha meningkatkan diri sekaligus mengasah intelektual untuk itu perlu diadakan koordinasi, tugas mengkordinasi ini adalah tugas supervisi.

\section{b. Melengkapi kepemimpinan madrasah}

Kepemimpinan yang demokratis perlu dikembangkan karena kepemimpinan itu suatu ketrampilan yang harus dipelajari dan itu harus melalui latihan terus menerus, dengan cara melatih dan memperlengkapi guru-guru agar mereka memiliki ketrampilan dalam kepemimpinan disekolah.

\section{c. Memperluas pengalaman guru-guru}

Pengalaman terletak pada sifat dasar manusia. Manusia ingin mencapai kemajuan yang maksimal perlu belajar dari pengalaman, bila ia mau belajar dari pengalaman nyata di 
lapangan melalui pengalaman baru ia dapat belajar untuk memperkaya dirinya dengan pengalaman belajar baru.

\section{d. Menstimulasi usaha-usaha madrasah yang kreatif}

Supervisi bertugas untuk menciptakan suasana yang memungkinkan guru-guru dapat berusaha meningkatkan potensi-potensi kreativitas dalam dirinya. Kemampuan untuk menstimulasi guru-guru agar mereka tidak hanya berdasarkan instruksi atasan, tapi mereka adalah pelaku aktif dalam proses belajar mengajar.

\section{e. Memberikan fasilitas dan penilaian secara berkelanjutan}

Untuk meningkatkan kualitas sumberdaya diperlukan penilaian secara terus-menerus karena dengan adanya penilaian dapat diketahui kelemahan dan kelebihan dari hasil dan proses belajar-mengajar. Penilaian itu harus bersifat menyeluruh dan kontinu.Menyeluruh berati penilaian menyangkut semua aspek kegiatan disekolah, kontinu dalam arti penilaian berlangsung setiap saat, yaitu pada awal, pertengahan diakhiri dengan melakukan sesuatu tugas.

\section{f. Menganalisissituasi pembelajaran oleh para guru}

Fungsi supervisi disini adalah menganalisis faktor-faktor yang mempengaruhi perbaikan belajar mengajar seperti mengenai aktivitas guru dan peserta didik akan memberikan pengalaman dan umpan balik tehadap perbaikan pembelajaran, tugas-tugas pembelajaran dan tujuan pendidikan.

\section{g. Memperlengkapi setiap anggota staf dengan pengetahuan yang baru dan keterampilan-keterampilan baru pula}

Disini supervisi memberi dorongan stimulasi dan membantu guru agar mengembangkan pengetahuan dalam keterampilan hal mengajar. Memadukan dan menyelaraskan tujuan-tujuan pendidikan dan membentuk kemampuan-kemampuan. Untuk mencapai suatu tujuan yang lebih tinggi harus berdasarkan pada tujuan-tujuan sebelumnya, setiap guru pada suatu saat sudah harus mampu mengukur kemampuannya. Mengembangkan kemampuan guru adalah salah satu fungsi supervise.

\section{Implikasi bagi Profesionalisme Guru-guru yang Disupervisi}

Penerapan supervisi akademik para kepala madrasah selaku supervisor se-KKM MI Kecamatan Gangga bagi guru di MI Riadlul Jannah NW Penjor berimplikasi positif dalam meningkatkan kompetensi pedagogik dan profesional guru serta memberikan pemahaman yang mendalam tentang peran seorang kepala madrasah selaku supervisor.Lebih jelasnya, implikasi atau dampak yang bisa dirasakan oleh setiap guru di MI Riadlul Jannah NW Penjor melalui kegiatan supervisi akademik oleh para kepala madrasah selaku supervisor seKKM MI Kecamtan Gangga Kabupaten Lombok Utara dapat dijabarkan sebagai berikut.

a. Peningkatan kompetensi pedagogik bagi guru 
Peningkatan kompetensi pedagogik bagi guru MI Riadlul Jannah NW Penjor melalui kegiatan supervisi akademik meliputi lima aspek kompetensi, yaitu: (1) pengenalan karakteristik anak didik, (2) penguasaan teori belajar dan prinsip-prinsip pembelajaran, (3) penguasan dalam hal pengembangan kurikulum, (4) penguasaan terhadap kegiatan pembelajaran yang mendidik, memahami dan mengembangkan potensi peserta didik, (5) penguasaan terhadap komunikasi yang efektif dengan peserta didik, penilaian dan evaluasi pembelajaran.

\section{b. Peningkatan kompetensi profesional bagi guru}

Peningkatan kompetensi profesional bagi guru MI Riadlul Jannah NW Penjor meliputi empat aspek kompetensi, yaitu: (1) penguasaan terhadap pengembangan standar kompetensi dan kompetensi dasar sesuai dengan mata pelajaran yang diampunya; (2) penguasaan terhadap materi ajar, konsep, pola pikir, dan struktur keilmuan secara luas dan mendalam sesuai mata pelajaran yang bidang yang diampunya; (3) penguasaan terhadap pengembangan materi ajar kedalam pembelajaran secara kreatif; dan (4) penguasaan terhadap pegnembangan keprofesionalan dengan melakukan tindakan reflektif melalui kegiatan Penelitian Tindakan Kelas secara berkelanjutan.

\section{c. Peningkatan pemahaman para guru tentang peran kemitraan yang semestinya terbangun antara kepala madrasah dengan guru}

Melalui kegiatan supervisi akademik oleh para kepala madrasah selaku supervisor, maka dewan guru di MI Riadlul Jannah NW Penjor memiliki tambahan pengetahuan dan pemahaman mendalam tentang peran kemitraan yang harus terbangun antara mereka bersama kepala madrasah antara lain: (1) Kepala madrasah membuat perencanaan program kerja, seperti penyusunan, pembuatan program semester bersama-sama dengan guru, dan terjadwalnya supevisi kelas, (2) Kepala madrasah memberi saran dan pemecahan masalah dalam menghadapi permasalahan yang berkaitan dengan tugas dan pekerjaan para guru, (3) Kepala madrasah berkonsultasi dan membuat keputusan serta mendelegasikan peranan, kepada para guru dalam melaksanakan kegiatan-kegiatan kerja, seperti pembenahan tenaga pengajar harus sesuai dengan bidangnya, (4) Kepala madrasah mengadakan supervisi, memberikanbimbingan dan latihan terhadap para guru terutama wali kelas dalam hal perkembangan anak asuhannya, dan program-program yang sudah ditentukan sebelumnya, dan (5) Kepala madrasah memberi pengakuan danimbalan kepada guru yang memliki prestasi dan kinerja memuaskan.

\section{KESIMPULAN}

Berdasarkan hasil penelitian tentang strategi peningkatan kompetensi pedagogik dan profesional guru di MI Riadlul Jannah NW Penjor melalui kegiatan supervisi akademik 
kepala madrasah teknik tukar peran, maka peneliti dapat menyampaikan kesimpulan sebagai berikut:

1. Urgensi pelaksanaan supervisi adakamik oleh para kepala madrasah anggota KKM dalam peningkatan kompetensi pedagogik dan profesional guru MI Riadlul Jannah NW Penjor sebagai sebuah program KKM berangkat dari hasil analisis kebutuhan peningkatan profesionalisme guru. Hal ini diperkuat juga dari sejumlah faktor penghambat yang dialami oleh guru dalam proses kegiatan pembelajaran di kelas.

2. Implementasi supervisi akademik kepala madrasah melalui teknik tukar peran dalam peningkatan kompetensi pedagogik dan profesional guru MI Riadlul Jannah NW Penjor dilakukan melalui kegiatan perencanaan, pelaksanaan dan evaluasi. Kegiatan perencanaan supervisi berlangsung dua tahapan yaitu perencanaan di tingkat KKM dan di tingkat madrasah. Kemudian pelaksanaan supervisi diawali dengan kegiatan pengkoreksian perangkat pembelajaran dan dilanjutkan dengan pelaksanaan supervisi di dalam kelas sesuai dengan strategi, pendekatan, dan teknik dari masing-masing supervisor. Selanjutnya implementasi terakhir adalah kegiatan evaluasi bersama untuk menyampaikan hasil supervisi kepada guru disertai dengan rekomendasi catatan dari masing-masing supervisor.

Implikasi supervisi akademik kepala madrasah teknik tukar peran bagi MI Riadlul Jannah NW Penjor secara garis besar terbagi menjadi dua bagian yaitu implikasi yang bermanfaat bagi pengembangan lembaga atau madrasah penyelenggara supervisi, dan juga implikasi positif bagi guru dalam mengembangkan kompetensi pedagogik dan kompetensi profesionalnya.

\section{DAFTAR PUSTAKA}

, (2008), Standar Kompetensi dan Sertifikasi Guru. Bandung: PT. Remaja Rosda Karya. Ametembun, (1975), Supervisi Pendidikan. Bandung: IKIP Bandung

Arikunto,S., (2004), Dasar-dasar Supervisi.Jakarta: Rineka Cipta

Bafadal, I., (2008), Peningkatan Profesionalisme Guru Sekolah Dasar dalam KerangkaManajemen Peningkatan Mutu Berbasis Sekolah. Jakarta: Bumi Aksara

Burhanuddin, dkk., (2007), Supervisi Pendidikan dan Pengajaran. Malang; Fakultas Ilmu Pendidikan UN Malang

Burhanuddin. (1994), Analisi Administrasi Manajemen dan Kepemimpinan Pendidikan.Jakarta: BumiAksara

Creswell, J. W., (2014), Research Design Pendekatan Kualitatif, Kuantitatif, dan Mixed, Terj.Achmad Fawaid, Cet. Ke-4.Yogyakarta: Pustaka Pelajar

Danim, S., \& Khairil, (2012), Profesi Kependidikan. Bandung:Alfabeta

Departemen Pendidikan Nasional, (2007) Pendidikan dan Pelatihan: Supervisi Akademik dalamPeningkatan, Profesionalisme Guru. Jakarta: Departemen Pendidikan Nasional DirektoratJenderal Peningkatan Mutu Pendidik dan Tenaga Kependidikan, 
Disdikpora RI. (2010), Permendiknas Nomor 28 Tabun 2010 Tentang Penugasan Guru SebagaiKepala Sekolah/Madrasah. Jakarta: Disdikpora Press

Hafifuddin, D., \& Tanjung, H. (2003), Manajemen Syariah dalam Praktek. Jakarta: Gema Insani.

https://ppg.uinmataram.ac.id. sebaran mahasiswa guru kelas mi rombel $1 \mathrm{~s} / \mathrm{d} 10$ https:/ / www.panduanmengajar.com Daftar LPTK Penyelenggara PPG Kemenag 2018.

Kompri, (2015), Manajemen Pendidikan: Komponen-Komponen ElementerKewajiban Sekolah. Yogyakarta: Ar-Ruzz Media.

Masaong, A. K. (2012), Supervisi Pembelajaran dan PengembanganKapasitas Guru. Bandung: Alfabeta.

Moleong, L. J. (2018), Metode Penelitian Kualitatif, Edisi Revisi. Bandung: PT. Remaja Rosdakarya.

Mulyana, D. (2001),.Metodologi Penelitian Kualitatif: Paradigma Baru Ilmu Komunikasi dan Ilmu Sosial Lainnya. Bandung: Remaja Rosdakarya.

Mulyasa, E. (2004), Menjadi Kepala Sekolah Profesional. Bandung: PT. Remaja Rosdakarya.

Noor, J. (2013), Metodologi Penelitian: Skripsi, Tesis, Disertasi dan Karya Ilmiah. Jakarta: Kencana Prenada Media Group.

Peraturan Menteri Pendidikan Nasional Nomor 13 Tahun 2007 tentang Standar KepalaSekolah/Madrasah.

Peraturan Menteri Pendidikan Nasional Nomor 13 Tahun 2007 tentang Standar Kepala Sekolah/Madrasah.

Prayitno, (2017), Konseling Profesional yang Berhasil.Jakarta: PT. Raja Grafindo Persada.

Putra, S. A. R., (2013), Desain Evaluasi Belajar Berbasis Kinerja. Yogyakarta: Diva Press.

Sahertian, P. A., (2000), Konsep Dasar Supervisi Pendidikan. Jakarta: Rineka Cipta.

Sahertian, P. A., (2010), Konsep Dasar dan Teknik Supervisi Pendidikan. Jakarta: Rineka Cipta.

Syafaruddin, dkk., (2012), Inovasi Pendidikan: Suatu Analisis Terbadap Kebijakan Baru Pendidikan. Medan: Perdana Publishing 